\title{
EROS ESTRANHO: REVERBERAÇÕES DO INSÓLITO EM NARRATIVAS DE CLARICE LISPECTOR
}

\section{STRANGE EROS: REVERBERATIONS OF THE UNUSUAL IN CLARICE LISPECTOR'S NARRATIVES}

\author{
Luciana Borges* $^{*}$ \\ UFCAT
}

Resumo: Este artigo apresenta uma leitura de algumas narrativas curtas de Clarice Lispector nas quais temas eróticos e/ou amorosos se manifestam conjuntamente a soluções narrativas que expressam o estranho ou o insólito ficcional. A combinação entre o estranhamento e o erotismo resulta em uma possível/impossível reconfiguração subjetiva de personagens que se deparam com "o mais secreto de si mesmas”, realizando na ficção a máxima de Georges Bataille (2004), para quem o erotismo é aquilo que "coloca o ser questão". Ressignificando as investiduras de gênero, a percepção de si e a relação com o Outro, as ocorrências do erótico insólito são um componente relevante do modo clariciano de narrar temas sexuais em sua ficção.

Palavras-chave: Clarice Lispector. Erotismo. Insólito.

\begin{abstract}
This paper presents a reading of some short stories of Clarice Lispector in which erotic or loving themes are manifested with narrative solutions that express the strange or unusual of fiction. The combination of strangeness and eroticism results in a possible/impossible subjective reconfiguration of characters which come across the "most concrete from themselves", achieving in fiction the Georges Bataille's maxim (2004), to whom eroticism is what "puts the being into question”. Reframing the gender endowments, the perception of herself and the relation with the Other, the occurrences of the unusual erotic are a relevant component of the Clarice's way of narrating sexual themes in her fiction.
\end{abstract}

Keywords: Clarice Lispector. Eroticism. Unusual.

Eu antes tinha querido ser os outros para conhecer o que não era eu. Entendi então que eu já tinha sido os outros e isso era fácil. Minha experiência maior seria ser o outro dos outros: e o outro dos outros era eu.

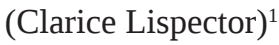

\footnotetext{
* Doutora em Letras e Linguística (Área de Concentração Estudos Literários) pela Universidade Federal de Goiás (2009). E-mail: <borgeslucianab@gmail.com>.

${ }^{1}$ Para não esquecer. Rio de Janeiro: Rocco, 2020c. p. 24.
} 


\section{NOTA INTRODUTÓRIA: CLARICE INSÓLITA OU TRAÇOS DO ESTRANHO NA FICCIONALIZAÇÃO DO EROTISMO}

A visita de um ser de Saturno. A invasão de visitantes mascarados no quarto de uma adolescente. Ruídos de passos de um falecido marido. O êxtase noturno conduzido por um ser andrógino. O sal do mar corpo adentro. A percepção do amor no enfrentamento com um búfalo enjaulado: As situações brevemente mencionadas reenviam a construções episódicas da ficção de Clarice Lispector, as quais confrontam personagens, bem como leitores e leitoras, com situações em que o insólito ou estranho vão se imiscuir nas tramas e dramas do cotidiano reconfigurado pela linguagem. Elaborado nas narrativas curtas que funcionam como instantâneo desse universo individual no qual a ficcionista se permite mergulhar em profundidade como principal traço da sua escrita, a presença do estranho ou do inusual é frequentemente apontada como motivo recorrente do modus operandi adotado por Clarice na tessitura de suas malhas ficcionais. São frequentemente apontados os processos de estranhamento da realidade e de si, vivenciados pelas personagens claricianas, como marca da autora desde os primeiros tempos da composição de sua fortuna crítica.

O insólito ou o estranho/ estranhamento são usualmente tratados do ponto de vista das tensões existenciais que circundam personagens, defrontadas com situações em que o cotidiano se torna algo inapreensível, uma vez constituído pela linguagem, inapreensível e impotente diante da "coisa". O tipo de ocorrência insólita que pretendemos perseguir nesse breve estudo é aquele que se relaciona em específico com situações em que o erotismo ou uma situação sexual ou amorosa é narrada. Mesmo nas situações eróticas, ainda que de modo pouco objetivo, como costuma ocorrer nos textos de Clarice, a repercussão ou efeito dos fatos nos sujeitos tem mais relevância do que os fatos materiais - ou supostamente ocorridos - em si.

Tomando como ponto de partida um procedimento, que a nosso ver constitui uma categoria narrativa a que denominamos erótico insólito, será feita a leitura analítica de elementos específicos dos contos "Miss Algrave" e "Ruído de Passos", de A via crucis do corpo (LISPECTOR, [1974] 1998); "As águas do mundo", publicado em Felicidade Clandestina (LISPECTOR, [1971] 2020a); “O búfalo” e "Mistério em São Cristóvão”, publicados em Laços de família (LISPECTOR, [1960] 2020b). O insólito, nas narrativas tratadas, será observado especialmente na relação como estranho, considerado seu principal mecanismo de materialização discursiva.

Em seu ensaio fundador sobre a obra de Clarice, intitulado $O$ drama da linguagem, Benedito Nunes aponta, a respeito de G.H., que essa personagem se apresenta dividida entre "[...] o desejo de seguir o apelo do mundo abismal e inumano onde vai perder-se, e a vontade de conservar sua individualidade humana” (NUNES, 1989, p. 59). Tal afirmação, a despeito de se direcionar a essa personagem em específico, poderia ser associada a uma repetição de tensionamentos que envolvem personagens claricianas como um todo, na galeria de personas com as quais a ficcionista vai nos presenteando ao longo da sua obra. Esse "apelo do mundo abismal" é expresso em uma cartografia variada de situações e perplexidades diante das quais as personagens, especialmente personagens femininas, são tentadas a se lançar nesse universo que extrapola o humano e coloca a personagem diante de dilemas profundos, nem sempre solúveis.

Um dos elementos dessa cartografia na qual o sujeito deve se defrontar com a diferença, como o "outro dos Outros” ou o “outro do eu”, parafraseando a própria Clarice em “A experiência 
maior”, minicrônica do livro Para não esquecer (LISPECTOR, 2020c), citada na epígrafe, é o enfrentamento do insólito, do inesperado, ou inusual. Para Flávio García:

Se o insólito não decorre normalmente da ordem regular das coisas, senão que é aquilo que não é característico ou próprio de acontecer, bem como não é peculiar nem presumível nem provável, pode ser equiparado ao sobrenatural e ao extraordinário, ou seja, àquilo que foge do usual ou do previsto, que é fora do comum, não é regular, é raro, excepcional, estranho, esquisito, inacreditável, inabitual, inusual, imprevisto, maravilhoso. (GARCÍA, 2007, p. 20).

No entanto, uma vez que o elemento imprevisto que rompe a normalidade, sendo gerador do insólito pode estar no próprio cotidiano, este se torna prenhe da potencialidade de se desconfigurar em sua periclitância. No universo clariciano, a vulnerabilidade do real é tamanha que a qualquer momento tudo pode se desmantelar e é justo, nesse desmantelamento, que o insólito compareça. Trata-se de uma escrita em "estado de emergência” que vai constituir o que Benedito Nunes denominou drama da linguagem: “[...] a narrativa é o espeço agônico do sujeito e do sentido - espaço onde ele erra, isto é, onde ele se busca - o deserto em que se perde e se reencontra para de novo perder-se, juntamente com o sentido daquilo que narra" (NUNES, 1989, p. 76). O espaço de agonia onde a linguagem se encerra termina por relacionar-se com o próprio estado de emergência do sujeito que deve, então, confrontar o cotidiano naquilo que ele tem de mais imprevisível, ainda que prosaico.

Sobre o não-familiar, o unheimlich, ou sobre os modos como a ruptura com o familiar ocorre em processos psíquicos, Sigmund Freud aproxima suas reflexões às proposições de Schelling, segundo as quais o estranhamento estaria ligado a algo que foi anteriormente reprimido:

Tal espécie de coisa angustiante seria justamente o inquietante, e nisso não deve importar se originalmente era ele próprio angustiante ou carregado de outro afeto. Segundo, se tal for realmente a natureza secreta do inquietante, compreendemos que o uso da linguagem faça o heimlich converter-se no seu oposto, o unheimlich, pois esse unheimlich não é realmente algo novo ou alheio, mas algo há muito familiar à psique, que apenas mediante o processo da repressão alheou-se dela. O vínculo com a repressão também nos esclarece agora a definição de Schelling, segundo a qual o inquietante é algo que deveria permanecer oculto, mas apareceu. (FREUD, 2010, p. 360).

Aquilo que usualmente inquieta personagens e situações estará em uma relação direta com a repressão e com a linguagem. Nas narrativas, situações eróticas estarão no emaranhado com o insólito que advém da interação dos sujeitos com o inumano (animal, vegetal ou mineral): o resultado é uma interação na qual o corpo humano se erotiza na relação com o inumano, provendo, então, a cena erótica.

E o que dizer do erotismo? Para estabelecer uma abordagem dos modos em que o erótico se manifesta nos contos a serem lidos, é preciso pensar que existem duas dimensões fundamentais de compreensão do erotismo no campo literário. A primeira, uma dimensão conceitual, em que somos interpeladas a pensar as configurações epistemológicas e filosóficas da vida erótica em termos das formulae mentis que regem a sexualidade humana. A segunda dimensão, formal 
ou estética, na qual pensamos as formas por meio das quais os temas se constituem em artifícios retóricos de linguagem, em imagens eróticas constituídas pela via da linguagem e que se materializam no texto literário.

Sobre a primeira dimensão, Georges Bataille (2004) propõe uma abordagem do erotismo como experiência interior, a partir do momento que a atividade erótica se distancia da atividade sexual de reprodução. Ao se distanciar de sua função instintiva mais óbvia, o erotismo é apresentado justamente naquilo que "coloca o ser em questão", ou seja, o jogo erótico prenuncia essa relação de continuidade e descontinuidade com o outro, no qual as partes constituídas estão sempre em vias de perder-se. Nesse sentido, o erótico é também um devir, um vir a ser no qual o eu e o outro se formam e desconformam na relação de interpenetração, recíproca ou não, que envolve o erotismo: “[...] o que está em jogo no erotismo é sempre a dissolução das formas constituídas. Repito: dessas formas da vida social, regular, que fundam a ordem descontínua das individualidades definidas que somos (BATAILLE, 2004, p. 31). Ao romper a ordem descontínua, o erotismo funda continuidades, no entanto também dissolve contornos definidos do eu e do outro.

A dimensão retórica diz respeito às formas pelas quais o texto expressa as chamadas cenas sexuais, de modo a criar sequências de ações e pensamentos que remetem aos aspectos de expressão da sexualidade. Assim, conforme a abordagem linguística de Dominique Maingueneau (2010), a retórica do erótico se difere da retórica do pornográfico em termos da criação dessas imagens mentais e sequências de ações narradas. O corpo erotizado, de alguma forma, constitui, em ambas as perspectivas, a baliza em torno da qual sensações corporais e psíquicas se articulam no contato como o outro.

O que os contos que analisamos traz de inusitado para nós, leitores e leitoras do erotismo na literatura, é uma dimensão de entrecruzamento entre a ruptura cotidiana, a experiência subjetiva do erotismo e o insólito ficcional como estratégia representativa do elemento de erotização no universo narrado. No caso, a erotização extrapola a dimensão da humanidade e se personifica em elementos não humanos, ou inumanos, para tomar de empréstimo a proposição de Evando Nascimento (2012). Esses elementos inumanos (um extraterrestre, um andrógino, a água do mar, homens zoomorfizados por máscaras, um mamífero de grande porte) são disparadores do efeito erótico de modo que podem até significar a fuga de um tratamento mais explícito dos temas sexuais. São também estratégias narrativas potentes para desconformar, tanto personagens como leitores, frente a seus estranhamentos. Nascimento (2012) parte do tensionamento da contraposição humano/ animal, fundada nas raízes da cultura ocidental para expandir a compreensão de não humano para um conjunto amplo de seres que são insidiosamente contrapostos aos humanos (seres dominados e colonizados) e localizados em posição hierarquicamente inferior ao homo sapiens em cuja centralidade se localiza toda a inteligibilidade do mundo tal qual conhecemos. Para o pensador citado,

[...] com efeito, animalidade e humanidade, em vez de identidades monolíticas, parecem constituir elementos diferenciados (em si mesmos e mutuamente) num vasto conjunto que estou chamando de "não humano". Todavia, por isso mesmo o não humano não é o oposto negativo do humano, nem inversamente sua face melhor. Seria simplesmente, eis a hipótese, aquilo que deu origem à emergência histórica de animais e homens, em sua vasta pluralidade. (NASCIMENTO, 2012, p. 31). 
Se fosse estabelecido que o não humano seria o negativo do humano, estaríamos de todo modo conservando a hierarquia anterior, de modo que a proposição do autor é tensionar esses elementos em torno da diferença, e não de uma contraposição em termos. A nossa proposta é considerar, nas partes analíticas específicas que se seguem, que o inumano erótico constitui um modo metaforicamente articulado de representar a profunda desconfiguração de si que o erotismo exige do sujeito, de modo que o enfrentamento com esse "outro do eu” é levado ao limite na aproximação erótica.

\section{CARTOGRAFIAS DO INSÓLITO ERÓTICO EM CONTOS CLARICIANOS: O ELEMENTO INUMANO NA CENA SEXUAL}

Para os fins que propusemos neste artigo, a presente seção passa a observar em alguns textos específicos os modos pelos quais a cena erótica se entrecruza ao estranho por meio da presença do inumano, resultando no uso do erótico insólito como estratégia narrativa. O primeiro texto a que lançamos nosso olhar é parte do conjunto de contos A via crucis do corpo, de 1974. Antes de abordar a construção do conto em específico, é necessário considerar que esse livro apresenta uma composição peculiar: em processo de autoficcionalização, Clarice Lispector explica no texto de abertura, a "Explicação", que seu editor havia proposto que ela escrevesse um livro de contos sobre "assunto perigoso”. A enunciação explícita sobre qual seria esse assunto não acontece no texto, de modo que, ao percorrê-lo, é que será possível vislumbrar qual seria esse assunto tão intimidante. Primordialmente, entendemos que o assunto seria sexo, no entanto, ao logo do livro, alguns contos não vão cumprir nem mesmo a função ficcional em termos de uma fabulação restrita, quanto mais a função de uma narrativa erótica: são textos que se assemelham mais ao formato de crônica que à forma do conto, nos sentidos usuais que a teoria literária atribui a esse gênero.

Em um estudo anterior que realizamos sobre esse conjunto de contos (BORGES, 2013), propusemos que a estratégia de composição do livro estabelece uma tensão entre a escrita da narração e a narração da escrita, ou, dito de outro modo, há uma fratura interna no conjunto, de modo que alguns textos apresentam a fabulação de uma história e acontecimentos com tensão própria da ficção curta e outros textos se apresentam como uma autorreflexão sobre o processo de escrita e sobre a escolha em ter aceito o convite do editor. A segunda composição configura uma linguagem cronística, com pretensões de uma ficcionalização de si como mulher autora, mas ao um só tempo também mãe, dona de casa, amiga de seus amigos que precisam de ajuda e escritora em crise com a atividade de escrever. Evidenciam-se questões de investidura de gênero, no cruzamento dos diversos papéis ocupados por Clarice como um ser compósito - mãe, escritora, mulher respeitável, dentre outros. Tais papéis poderiam ser comprometidos negativamente em termos de sua imagem como persona pública ao escrever textos, cuja recepção poderia não ser entusiasmada ou mesmo acusatória. Tal identidade fraturada vai se desdobrar nessa fratura do texto, de modo especular, como uma mise en abyme do eu que escreve em encaixe com o eu que vive e pensa o processo a um só tempo enquanto escreve.

Quanto ao tratamento dos temas sexuais, concentra-se no que chamamos de retórica da contenção (BORGES, 2013, p. 367), na qual a função narradora se abstém, por vezes por declarado pudor, por vezes por estratégia retórica, de narrar determinados acontecimentos que 
permanecem, portanto, em seu locus obscenum, ou seja, etimologicamente falando, para utilizar a terminologia apropriada do teatro, atrás da cena, atrás dessas “cortinas” do texto, com a barreira linguística imposta pela narradora.

Em seu estudo sobre materiais pornográficos, Linda Williams $(2004)^{2}$ menciona a origem latina do termo obsceno, produzindo um neologismo que funciona ao mesmo tempo para

[...] indicar a normalidade com que se encara a explicitude das imagens eróticas levadas para a esfera pública e as restrições que se impõem a essa veiculação. Assim, a pornografia está sempre on/scene, jogo entre o ob, radical latino que semantiza o escondido, velado e a preposição on, do inglês, indicando que o sexo é sempre parte da cena humana, inesgotável fonte de questionamentos em sua faceta pública ou privada. (BORGES, 2013, p. 108).

Desse modo, podemos pensar que Clarice, ao fazer o jogo entre o revelar e o esconder em suas narrativas, aciona esses mecanismos retóricos que circundam a produção de temas sexuais na arte e na literatura, seja ela de ênfase mercadológica, ou não. É nesse contexto de dubiedade em torno do narrar ou não narrar o sexo, entre as agruras e angústias da enunciação que o insólito comparece no primeiro conto do livro.

"Miss Algrave”, ao nos apresentar a personagem Ruth, move a narrativa nessa atmosfera de contenção, por meio da qual a protagonista é inicialmente composta. Puritana, religiosa, reacionária, contida. A continência de Ruth se revela em seus hábitos que negam e invisibilizam a corporeidade física, anulam qualquer traço de satisfação erótica: "Solteira, é claro, virgem, é claro. Morava sozinha em uma cobertura em Soho. Nesse dia tinha feito suas compras de comida: legumes e frutas. Porque comer carne ela considerava pecado” (LISPECTOR, 1998, p. 13). Nesse contexto de restrições corporais e intelectuais, uma vez que Ruth não se permite nem olhar e nem mentalizar cenas de sexo ou mesmo cenas de afeto, surgirá o extraterrestre Ixtlan, ao qual será atribuída a função de iniciar Ruth nos prazeres do corpo e da carne. A apresentação de Ixtlan é emblemática de sua inumanidade: “Eu sou um eu” (LISPECTOR, 1998, p. 16). Ixtlan não é humano nem animal, é apenas um “eu” que veio para amá-la. A natureza dele, invisível, mas sensível como no mito de Eros e Psiqué3 ${ }^{3}$ é uma natureza híbrida, fria, mas que causa um frisson em Ruth; tem uma coroa de cobras na cabeça a lembrar os cabelos da Medusa; usa uma manto fosforescente cor púrpura que ilumina seu corpo como um Deus. Sua natureza estranha e compósita não importa. O que importa é que ele leva Ruth ao êxtase supremo. O aproveitamento das remissões a Eros no mito de Psiqué recupera um dos aspectos de Eros: nesse mito, inicialmente Eros é o monstruoso, uma vez que, não tendo se revelado em sua natureza divina à sua esposa que havia sido condenada a desposar um desconhecido, as narrativas correntes sobre o deus, especialmente no meio familiar de Psiqué, era de que ela havia sido entregue a um monstro que, em algum momento, a devoraria. Nessa versão do

\footnotetext{
2 "If obscenity is the term given to those sexually explicit acts that once seemed unspeakable, and were thus permanently kept off-scene, on/scenity is the more conflicted term with which we can mark the tension between the speakable and the unspeakable which animates so many of our contemporary discourses of sexuality" (WILLIANS, 2004, p. 4). Tradução nossa: "Se obscenidade é o termo dado aos atos sexualmente explícitos que antes pareciam indizíveis e, portanto, eram mantidos permanentemente fora da cena, on/scenity é o termo mais conflituoso com o qual podemos marcar a tensão entre o falável e o indizível que anima muitos de nossos discursos contemporâneos de sexualidade”.

${ }^{3}$ Para versões do mito grego e suas interpretações mais recorrentes, consultar, por exemplo, Brandão (1995).
} 
mito de Eros, em que se associa a Psiqué, a dimensão teogônica se apresenta de parelha com a teratológica. Analogamente, Ixtlan é também deus e monstro, concentrando em si o prazer nunca experimentado por Ruth, o divisor de águas de sua existência.

O gozo do estranho, nesse caso, opera uma verdadeira transformação na protagonista, que se sente como um aleijado que repentinamente não precisa mais de seu cajado. Ruth não apenas abandonará o moralismo, como adotará uma conduta lasciva ao perceber que o exercício pleno da sexualidade não era algo condenável: "Com ele não fora pecado e sim uma delícia” (LISPECTOR, 1998, p. 18). A visita de Ixtlan, que podemos ler também como uma projeção do desejo contido de Ruth e como estratégia performática de liberação das amarras da coletividade cristã da qual ela havia se investido, instaura o insólito na narrativa. Um acontecimento que não tem paralelo com a realidade e que, aproximando-se do estranho ficcional, opera todo o estranhamento de Ruth em relação à realidade anterior: vinho tinto é bom, carne é delicioso, vestir vermelho é lindo, seduzir o chefe casado é estratégia de ascensão econômica, tudo isso passa a ser parte de uma orgia de sentidos que descortina para a personagem um mundo totalmente novo e uma Ruth totalmente reconfigurada em sua identidade.

Em “Ruído de passos”, também de A via crucis do corpo, o defrontar-se com o insólito virá após a visita de Dona Cândida Raposo, uma senhora de 81 anos de idade que, a despeito de sua velhice, ainda sente desejo sexual. Ao seguir o conselho do médico e encorajar-se à masturbação, Dona Cândida, apesar do prazer do orgasmo sentido, sente-se solitária e triste, com culpa por não conseguir resistir à vontade de sexo. Fogos espocam, mas são fogos mudos, como a indicar a artificialidade e incompletude com a qual ela sente todo o processo:

Nessa mesma noite deu um jeito e solitária satisfez-se. Mudos fogos de artifício. Depois chorou. Tinha vergonha. Daí em diante usaria o mesmo processo. Sempre triste. É a vida, senhora Raposo. Até a benção da morte.

A morte.

Pareceu-lhe ouvir ruído de passos. Os passos de seu marido Antenor Raposo. (LISPECTOR, 1998, p. 56).

Os ruídos dos passos do marido morto convocam o insólito e um suposto sobrenatural para esse que é o conto mais curto de toda a coletânea, um verdadeiro instantâneo, aquele soco do knockout do qual nos fala Julio Cortázar (1993) em sua teoria do conto. Ainda que o texto não tenha grande tensão narrativa, o desejo reprimido de Dona Cândida estabelece esse suspense em relação à solução de um problema que, pelas questões relativas à sexualidade na velhice em contexto ocidental, aparentemente é insolúvel. O estranho, nesse caso, é essa projeção de uma instância repressora, personificada na figura do fantasma do marido morto. Ao presenciar do além a sua viúva se permitindo ter prazer, reaparece de modo abstrato para assombrá-la, como a querer tomar de volta aquilo que sempre lhe pertencera: o corpo e o prazer da esposa. Como a lembrar Freud, já citado, o desejo reprimido faz emergir o estranho: uma realidade antes familiar, a casa de Dona Cândida, torna-se então assombrada pelo espectro do homem que já não vive, mas que ali se aninha em toda uma configuração patriarcal sobre o desejo das mulheres.

Por outro lado, pela polissemia que usualmente as narrativas suscitam, seria possível ler também, em outra perspectiva, a chegada do fantasma de Antenor Raposo como um sintoma da recuperação da dimensão erótica da personagem idosa. Uma vez que o corpo das velhas é 
colocado nas bordas do desejo, em uma sociedade em que exercício da sexualidade e juventude são indissociáveis, o prazer solitário é uma transgressão. No caso dessa protagonista, a interdição sobre o corpo se direciona diretamente às restrições da idade, já que é o fato de ela ter 81 anos que a impede de ter um parceiro.

Como afirma Simone de Beauvoir (1990), a velhice fica sendo um tabu maior e algo mais temido do que a própria morte, e estereótipos sobre a velhice tornam o velho um ser de exceção, que deve ser apagado da sociedade por meio do apagamento do seu corpo. Umberto Eco (2007), em seu livro História da feiúra, dedica um capítulo especial à feiura feminina. O autor ressalta que, na tradição antifeminina, o tema do vitupério à mulher feia sempre encontrou grande sucesso, o autor observa que, nas mulheres, a ausência da beleza ou a desproporção das formas causada pela anatomia ou pela velhice constantemente se irmana com a manifestação de caracteres internos negativos como a malícia interior, a maldade, a tendência a mentir e enganar. Na Idade Média, a velha feia é sempre símbolo da decadência física e moral, sendo a fonte de inúmeras cantigas e poemas misóginos e maledicentes. Na distinção entre o feio-em-si e o feio formal ${ }^{4}$, a velhice desponta como parte do primeiro, a velhice é constantemente associada à feiura. No caso da velhice feminina, Beauvoir ressalta que, na sociedade patriarcal e androcêntrica, a perda da beleza é sobremaneira perniciosa:

Já que o destino da mulher é ser, aos olhos do homem, um objeto erótico, ao tornar-se velha e feia ela perde o lugar que lhe é destinado na sociedade: torna-se um monstrum que suscita repulsa e até mesmo medo; do mesmo modo que para certos primitivos, ao cair fora da condição humana a mulher assume um caráter sobrenatural: é uma mágica, uma feiticeira com enormes poderes sobrenaturais. (BEAUVOIR, 1990, p. 152).

A representação das mulheres por meio da teriomorfia, ou seja, por meio da sua monstrualização, associa-se diretamente à velhice, e as mulheres velhas são vistas como corpos repulsivos e abjetos, sem direito ao desejo e ao prazer. Acionar o insólito para resolver simbolicamente o problema da falta de parceiro pode ter sido o mecanismo encontrado na narrativa para, de algum modo, devolver a Dona Cândida um pouco da sua humanidade e da sua feminilidade negada.

Após percorrermos essas instâncias do insólito no campo das ocorrências de um ser alienígena com Ixtlan e o campo do sobrenatural com o fantasma do marido, os próximos contos analisados se direcionam para o mundo animal e mineral. “As águas do mundo”, publicado em Felicidade Clandestina (LISPECTOR, 2020a), é um conto que pertence ao conjunto de textos que figuram em livros diversos de Clarice Lispector, ora como conto, ora como crônica, ora como capítulo do romance Uma aprendizagem ou o livro dos prazeres (LISPECTOR, 2020d), quando a mulher, inominada no conto e na crônica, é simbioticamente investida como Lori.

No conto, a mulher está sozinha de frente ao mar em uma manhã com a praia vazia. E a narrativa indica a identificação desses dois seres que se confrontam, a mulher com sua solidão, o mar com sua imensidão potente: “Aí está ele, o mar, a mais ininteligível das existências não

\footnotetext{
${ }^{4}$ Eco (2003, p. 19-20) ressalta três categorias do feio: o feio em si, ou seja, aquilo que, independentemente de época ou cultura, tenderá a ser sempre qualificado como feio; o feio formal, ou seja, aquilo que expressa “[...] o desequilíbrio na relação orgânica entre as partes de um todo" (desproporção) e, por último, a representação artística de ambos que, em última instância, pode converter a feiura em beleza estética pela maestria do artista.
} 
humanas. E aqui está a mulher, de pé, na praia, o mais ininteligível dos seres vivos” (LISPECTOR, 2020a, p. 136). A protagonista adjetiva o mar como uma existência não humana, e é diante dessa imensidão que, a partir do ato de beber o mar, ela vai partilhar dessa natureza singular. Beber a água do mar se transmuta em um ato erótico, a partir do momento que este é colocado em similitude com o esperma: “Com a concha das mãos faz o que sempre fez mar e, com a altivez dos que nunca darão explicação nem a eles mesmos: com a concha das mãos cheia de água, bebe em goles grandes, bons” (LISPECTOR, 2020a, p. 137-138). Os goles grandes fecundam o corpo ressequido, como a indicar um processo de simbiose de sua natureza humana com um elemento ininteligível que, a partir de sua inteligibilidade, paradoxalmente faz com ela se defronte consigo mesma e se reconheça.

E era isso que lhe estava faltando: o mar por dentro como o líquido espesso de um homem. Agora ela está toda igual a si mesma. A garganta alimentada se constringe pelo sal, os olhos avermelham-se pelo sal secado pelo sol, as ondas suaves lhe batem e voltam pois ela é um anteparo compacto. (LISPECTOR, 2020a, p. 138).

O gozo do inumano, no caso, o mar, faz com que ela se fortaleça, como um anteparo contra o qual as ondas podem se chocar e não será abalado. A reconfiguração pela qual a personagem passa a partir dessa junção com a natureza líquida do mar nos reenvia às reflexões anteriores, segundo as quais o insólito das situações pode vir associado ao erotismo em suas diversas configurações. No caso desse conto, a sacralidade do ato de beber o mar indica a conjunção cósmica com esse elemento natural que promove a reconciliação da personagem consigo mesma, em uma continuidade que substitui a sensação de descontinuidade e solidão vivenciadas antes da experiência erotizada de beber o sal do mar, bem no sentido batailliano do erotismo que adquire dimensões para além dos corpos de indivíduos e de humanos.

Em relação ao conto “O búfalo”, de Laços de família (LISPECTOR, 2020b), o confronto dá-se com a animalidade em seu estado mais bruto, uma vez que a protagonista se dirige a um jardim zoológico para tentar aprender o ódio ao amante que a abandonara. O conto expressa justamente a presença indubitável na qual podem ser identificados “o animal no homem e o homem no animal”, tornando fluida uma diferenciação radical que a humanidade sempre tentou estabelecer entre a humanidade e a animalidade. Para Evando Nascimento (2012, p. 23), a colonização dos homens sobre os animais “[...] trata-se de um grande aparato discursivo e institucional para justificar todo tipo de atrocidade contra aqueles a quem consideramos demasiado cruéis”. Dessa forma, os animais são sempre colocados como inferiores e exploráveis na escala zoológica, e humanos poderiam dispor de seus corpos para qualquer uso: alimentação, transporte, experiências científicas, companhias, trabalho escravo, trabalho sexual.

Toda essa exploração se justificaria pela suposta inferioridade animal, pela sua irracionalidade e pela sua violência que precisa sempre ser domesticada. Animais que são vistos como feras são ainda mais estigmatizados, uma vez que não cederiam à docilidade exigida pelos seres humanos de seus corpos. “[...] o animal pode ser violento, mas do ponto de vista da cultura, a besta e a fera são animais por assim dizer desembestados, entregues a seus mais virulentos instintos”, afirma Evando Nascimento (2012, p. 21). É bastante interessante acionar essa afirmação para ler a busca da protagonista pelo ódio no jardim zoológico: 
Então, nascida do ventre, de novo subiu, implorante, em onda vagarosa, a vontade de matar - seus olhos molharam-se gratos e negros numa quase felicidade, não era o ódio ainda, por enquanto apenas a vontade atormentada de ódio como um desejo, à promessa do desabrochamento cruel, um tormento como de amor, a vontade de ódio se prometendo sagrado sangue e triunfo, a fêmea rejeitada espiritualizara-se na grande esperança. Mas onde, onde encontrar o animal que lhe ensinasse a ter seu próprio ódio? (LISPECTOR, 2020b, p. 124-125).

A busca pelo ódio como uma aprendizagem da animalidade: essa parece ser a tônica dessa primeira parte do conto. De fato, como afirma Bataille,

[...] as chances de sofrer são ainda maiores na medida em que apenas o sofrimento revela a inteira significação do ser amado. A possessão do ser amado não significa a morte, ao contrário, mas a morte está envolvida em sua procura. Se o amante não pode possuir o ser amado, pensa às vezes em matá-lo: frequentemente preferia matá-lo a perdê-lo, em outros casos, ele deseja a própria morte (BATAILLE, 2004, p. 33).

Ao encontrar o búfalo como sendo a fonte desse ódio que ela perseguia para se livrar da dor de ser “uma fêmea rejeitada”, a mulher passará por uma série de ocorrência fisiológicas que indicam seu estado de desordenação interna, sua profunda fratura na ruptura erótica que marca a descontinuidade amorosa. Ela sente tonturas, vertigens, calafrios, até se levantar para o enfrentamento final com o búfalo que resgata a dimensão erótica do encontro com o não humano: "Presa como se sua mão tivesse grudado para sempre ao punhal que ela mesma cravara. Presa, enquanto escorregava enfeitiçada ao longo das grades. Em tão lenta vertigem que antes do corpo baquear macio a mulher viu o céu inteiro e um búfalo” (LISPECTOR, 2020b, p. 129)

Esse, o desfecho do conto: a perda dos sentidos, como uma pequena morte, metáfora frequente do orgasmo. Antes, “um primeiro fio de sangue negro” (LISPECTOR, 2020b, p. 129) havia escorrido de seu corpo, como a demarcar a sua existência fêmea, essa fêmea que menstrua e perpetua a espécie a partir da junção com um seu igual. Ao perder os sentidos no suposto encontro com o ódio, a ambiguidade da relação erótica e seu poder desagregador, apontados por Bataille (2004), são atualizados. O próximo conto não apresenta um elemento animal em sua literalidade, mas explora o imaginário animal na sua composição da ocorrência erótica.

“Mistério em São Cristóvão”, também de Laços de família (LISPECTOR, 2020b), mostra o acontecimento insólito construído de forma metafórica a partir da composição de quatro personagens centrais: três rapazes que se dirigem a um baile de carnaval fantasiados com máscaras de galo, touro e demônio. No caminho, decidem invadir um jardim para roubar jacintos que enfeitariam suas fantasias. A quarta personagem é uma jovem de 19 anos que, em um dia trivial, após jantar com a família, depara-se com os rapazes roubando os jacintos. No entanto, o roubo aparentemente inocente dos jacintos terá desdobramentos sombrios que não são bem explicados no conto, e são responsáveis por sua atmosfera insólita.

Os rapazes, ainda que humanos, partilham da natureza animal e inumana ao estarem fantasiados de animais e demônio, de modo que o enfrentamento da personagem feminina com esse não humano será ressaltado a partir desse travestimento carnavalesco. O Carnaval é também esse momento de suspensão da lei e da ordem, em que a moral se configura elástica, por meio das transgressões permitidas, da subversão e da paródia dos costumes. É justamente 
quando o galo está a quebrar a talo da primeira flor que o inesperado irá acontecer: a moça vê a cena da invasão, a quebra da haste e, assustada, lança um grito agudo no silêncio da noite, desencadeando a fuga dos mascarados: "Mal porém quebrara a haste do jacinto maior, o galo interrompeu-se gelado. Os dois outros pararam num suspiro que os mergulhou em sono. Atrás do vidro escuro da janela estava um rosto branco olhando-os” (LISPECTOR, 2020b, p. 108).

O inusitado da situação faz com seja possível uma leitura metafórica dos acontecimentos, já que, a partir do grito, toda a tranquilidade da casa será desfeita. Os elementos do conto sugerem que a quebra do talo da flor possa ser lida como ruptura erótica do estado de virgindade da moça, como se esta fora um jardim secreto, profanado pela invasão dos mascarados. Do enfrentamento com o desconhecido que invade o jardim, surgirá uma alteração física na adolescente que, a ser socorrida pela família está confusa. Ao quebrar o talo da flor, o elemento masculino rompe com violência esse gineceu metafórico, profanando a inocência e alçando a moça a uma condição de amadurecimento forçado, representado pelo cabelo branco que surge em sua testa.

A mocinha nada sabia explicar; parecia ter dito tudo no grito. Seu rosto apequenara-se claro - toda a construção laboriosa de sua idade se desfizera, ela era de novo uma menina. Mas na imagem rejuvenescida de mais de uma época, para horror da família, um fio branco parecera entre os cabelos da fronte. (LISPECTOR, 2020b, p. 110).

O fio branco entre os cabelos indica a reconfiguração subjetiva da personagem e o insólito que se instaura pelo aparecimento desse inexplicável fenômeno nos reenvia à máxima batailliana, segundo a qual o erotismo é, primordialmente, o lugar da violação. A ruptura simbólica acontece justamente nos limites entre a infância e uma suposta idade adulta, restando a adolescência em suspenso, adiada ou inexistente em um átimo. A violação, nesse caso, é tratada em termos implícitos em profundidade, no vago das entrelinhas e muito ao estilo clariciano de narrar.

\section{CONSIDERAÇÕES FINAIS OU QUE ESTRANHEZAS TEM CLARICE}

Ao reunir os contos propostos no presente artigo, consideramos como as narrativas acionam processos relacionados ao insólito, em termos de uma representação do erotismo no enfrentamento com o não humano. Tal expediente fabular, ainda que com variações, configura, a nosso ver, uma estratégia da ficção clariciana no tratamento do erótico, podendo, inclusive, ser perscrutado em outras narrativas da autora, como procedimento ficcional recorrente. Seja por meio de elementos animais, como o búfalo, minerais como o mar, seres compósitos como o alienígena e os mascarados ou sobrenaturais como o fantasma, o insólito ficcional irrompe como esse componente que, ao fissurar o cotidiano, obriga as personagens a se reconfigurarem do ponto de vista dos processos psíquicos que estão vivenciando.

Interessante é observar que as ocorrências se constituem em termos da construção de personagens femininas que se deparam com a necessidade de transformação identitária, afirmação de autonomia ou amadurecimento afetivo na relação erótica. O uso do insólito, do estranhamento frente ao incomum por meio do elemento erótico não humano, também pode ser lido também em perspectiva de gênero. As investiduras do gênero agem com mais intensidade sobre a sexualidade feminina que, em contexto patriarcal, é sempre vista como passiva e retroflexa, podendo resultar nas soluções narrativas lidas neste artigo. 
Em perspectiva complementar, a partir da noção de dispositivo da sexualidade proposta por Michel Foucault (2001), em História da sexualidade, é possível compreender os processos, que, ligados à autoria feminina, reenviam a modos de compor o erótico em termos de figuras retóricas. Ao compor a retórica da sexualidade nos territórios limítrofes do dito e do não dito, na atmosfera dos segredos, dos interditos sempre confessados, a sociedade ocidental estabelece um terreno movediço para o exercício do sexo e sua colocação em discurso. Dessa forma, é possível pensar também que o insólito erótico como categoria analítica ilumina algumas questões que nem sempre são evidentes no campo dos estudos do erotismo ou dos temas sexuais na literatura. Questões relativas aos modos como as expectativas de gênero podem afetar escolhas de composição narrativa ou afetar a recolha dos temas a serem tratados na ficção, vide o caso da escrita de A via crucis do corpo (1998), em específico, são evidências dessa repercussão no campo estético da literatura.

Se há uma repressão em termo do exercício da sexualidade, essa repressão poderá também lançar suas sombras sobre o campo literário, de modo que a escrita do erótico sempre foi considerada uma escrita de bordas, paraliterária ou mercadológica, associada à ideia de menor valor ou de menor qualidade estética. Ao associar o erótico ao insólito e ao inumano, de modo que o estranho clariciano se atualiza, as narrativas se estabelecem em terreno complexo no qual o erótico se adensa e se relaciona tanto a questões existenciais quanto a questões de gênero. Ao se defrontar com o Outro não humano, a própria sexualidade das personagens é tensionada de modo implícito ou explicito, caracterizando uma experiência subjetiva e não apenas física.

Podemos pensar, também, que o caráter transgressivo que a vida erótica adquire, portanto, tem como desdobramento o fato de que qualquer material escrito ou imagético que remeta a temas sexuais receba interdição imediata e possa circular apenas em ambientes permitidos. A essas interdições se liga também a interdição de práticas sexuais não normativas, às quais serão reservadas, segundo Judith Butler (2003), em Problemas de gênero: feminismo e subversão da identidade, um lugar de abjeção a partir do momento que os corpos vão performar de modo diverso ao que lhes foi atribuído. Para a autora, a condição coercitiva do gênero se relaciona a uma repetição estilizada: “[...] os gêneros são instituídos pela estilização do corpo e, por isso, precisam ser entendidos como o processo ordinário pelo qual gestos corporais, movimentos e ações de vários tipos formam a ilusão de um Eu atribuído de gênero” (BUTLER, 2019, p. 214). O resultado é que os rígidos códigos do gênero agirão sobre a sexualidade a partir do que a filósofa denomina heterossexualidade compulsória.

Do ponto de vista do qual falamos, o erotismo expressará quase sempre, nas proposições teóricas de sua formulação, aspectos da vida sexual heterorientada e outros tipos de erotismo receberão marcadores semânticos de diferenciação, como acontece em homoerotismo. Por outro lado, a expressão da sexualidade também se ressentirá desses códigos rígidos do gênero. Contudo, para as mulheres, confinamento do sexo à apropriação de seu outro, o homem, acarretará consequências bastante duras do ponto de vista do erotismo como experiência existencial.

É também Foucault (2001) que nos alerta para o fato de que o ocidente, por meio das estratégicas elaborações sobre sexo, corpo, desejo não teria construído uma arte erótica (ars erótica) e sim uma ciência da sexualidade (scientia sexualis). Ao tentar confinar a sexualidade ao dispositivo do casamento monogâmico, estabelecendo regras rígidas ligadas tanto à reprodução quanto à moralidade, o discurso ocidental sobre a sexualidade reservou para si um lugar mais 
de explicação conceitual do que de exercício efetivo, de modo que as dimensões do erotismo são afetadas por tais aspectos.

Mesmo em termos teóricos, há algumas ocorrências sobre os modos como a repetição do gênero da qual nos fala Butler podem afetar as formulações conceituais. No ensaio de Bataille (2004, p. 31), já citado, quando ele menciona, por exemplo, a “dissolução das formas constituídas” no processo de estabelecimento da continuidade erótica, o autor aborda que a parte dissolvida é sempre feminina, posto que sempre passiva. Já Francesco Alberoni (1988) apresenta diferenciações bastante essencialistas entre o que ele chama de erotismo feminino e masculino, quase sempre em relação ao par atividade/passividade. No estudo histórico de Alexandrian (1994) sobre literatura erótica, ele estabelece um elenco de características que seriam exigidas para a expressão do erotismo feminino em termos estéticos e temáticos de modo a desconsiderar o que não se adequa à sua grade de validação.

Nesse contexto, reinventar na ficção os modos de expressão do erótico, como vimos nos contos selecionados, constitui também uma ruptura com os modos estabelecidos, com as tábuas de medida que supostamente devem ser seguidas na composição de um texto fictício de temática sexual. Tendo em vista essas considerações, encontrar na ficção clariciana esse conjunto de textos que trazem uma forma singular de representação do erótico nos mostra, mais uma vez, a atualidade da obra de Clarice Lispector, na qual elementos expressivos não se limitam a repetir um conjunto de composições preestabelecidas. Por meio da inserção do estranhamento, temático e formal, do estranhamento dessa linguagem agônica e fraturada para a qual nos chamam atenção Benedito Nunes (1989) e Evando Nascimento (2012), do estranhamento de si e do outro, do estranhamento de toda a suposta realidade, consegue reconfigurar aspectos relevantes da representação do feminino e da autoria feminina do erotismo na literatura. Ao colocar suas personagens em tensão simbólica limítrofe entre um antes e um depois no enfrentamento do estranho na cena erótica, como se nos olhassem de um abismo inexorável, os textos de Clarice Lispector nos descortinam possibilidades do erotismo que apenas uma obra instigante como a clariciana é capaz de descortinar.

\section{REFERÊNCIAS}

ALBERONI, F. O erotismo. Rio de Janeiro: Rocco, 1988.

ALEXANDRIAN, S. História da literatura erótica. Rio de Janeiro: Rocco, 1994.

BATAILlE, G. O erotismo. São Paulo: Arx, 2004.

BEAUVOIR, S de. A velhice. Rio de Janeiro: Nova Fronteira, 1990.

BORGES, L. O erotismo como ruptura na ficção brasileira de autoria feminina: um estudo de Clarice Lispector, Hilda Hilst e Fernanda Young. Florianópolis: Editora Mulheres, 2013.

BRANDÃO, J. de S. Eros e Psiqué. In: BRANDÃO, J. de S. Mitologia Grega. v. 2. Petrópolis: Vozes, 1995. p. 209-251.

BUTLER, J. Problemas de gênero: feminismo e subversão da identidade. Rio de Janeiro: Perspectiva, 2003. 
BUTLER, J. Atos performáticos e a formação dos gêneros: um ensaio sobre fenomenologia e teoria feminista. In: HOLLANDA, H. B. de (org.). Pensamento feminista: conceitos fundamentais. Rio de Janeiro: Bazar do Tempo, 2019. p. 213-230.

CORTÁZAR, J. Valise de cronópio. São Paulo: Perspectiva, 1993.

ECO, U. Introdução. In: ECO, U. (org.). História da feiúra. Rio de Janeiro: Record, 2007. p. 8-20. FOUCAULT, M. História da sexualidade I: a vontade de saber. Rio de Janeiro: Graal, 2001. FREUD, S. O inquietante (1919). FREUD, S. Obras completas. v. 14. Tradução Paulo César de Souza. São Paulo: Companhia das Letras, 2010. p. 329-376.

GARCÍA, F. O “insólito” na narrativa ficcional: a questão e os conceitos na teoria dos gêneros literários. In: GARCÍA, F. (org.) A banalização do insólito: questões de gênero literário mecanismos de construção narrativa. Rio de Janeiro: Dialogarts, 2007. p. 10-22.

LISPECTOR, C. A via crucis do corpo. Rio de Janeiro: Rocco, 1998.

LISPECTOR, C. Felicidade Clandestina. Rio de Janeiro: Rocco, 2020a.

LISPECTOR, C. Laços de família. Rio de Janeiro: Rocco, $2020 \mathrm{~b}$.

LISPECTOR, C. Para não esquecer. Rio de Janeiro: Rocco, 2020c.

LISPECTOR, C. Uma aprendizagem ou o livro dos prazeres. Rio de Janeiro: Rocco, 2020d.

MAINGUENEAU, D. O discurso pornográfico. São Paulo: Parábola Editorial, 2010.

NASCIMENTO, E. Clarice Lispector: uma literatura pensante. Rio de Janeiro: Civilização Brasileira, 2012.

NUNES, B. O drama da linguagem: uma leitura de Clarice Lispector. São Paulo: Ática, 1989.

WILLIAMS, L. (Ed.). Porn studies. Durham and London: Duke University Press, 2004. 